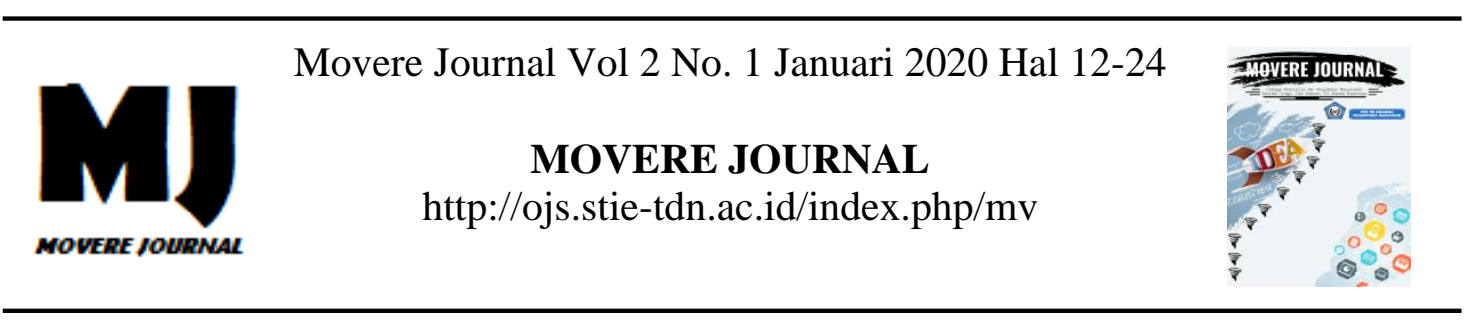

\title{
ANALISIS PENILAIAN KINERJA PEGAWAI UNTUK MENGETAHUI KUALITAS KELAYAKAN KERJA MENGGUANAKAN JARINGAN SYARAF TIRUAN BACKPROPAGATION
}

\author{
Hamdina $^{(1)}$, Zul Rahmat ${ }^{(2)}$, Wahyuddin $\mathbf{S}^{(3)}$ \\ AMIK Lamappapoleonro Soppeng
}

\begin{abstract}
Abstrak : Analisis Penilaian Kinerja Pegawai untuk Mengetahui Kualitas Kelayakan Kerja Menggunakan Jaringan Syaraf Tiruan Backpropagation, dibimbing oleh Syahnur Said selaku ketua dan Anis Saleh sebagai wakil pembimbing. Tujuan penelitian ini adalah untuk mengetahui kualitas kelayakan kerja pegawai berdasarkan pada variabel pendidikan, keterampilan, pengalaman kerja dan motivasi pada Dinas Kependudukan dan Pencatatan Sipil Kab. Maros menggunakan analisis program Jaringan Syaraf Tiruan (JST) Backpropagation. Penelitian ini dilaksanakan pada Kantor Dinas Kependudukan dan Pencatatan Sipil Kabupaten Maros dengan sampel 59 Pegawai. Metode yang digunakan untuk mengetahui kualitas kelayakan kerja ini adalah salah satu model komputasi yaitu Jaringan Syaraf Tiruan Propagasi Balik. Hasil penelitian menunjukkan bahwa sebanyak 21 orang pegawai nilai kinerjanya Baik dan 38 orang pegawai nilai kinerjanya Cukup Baik. Kualitas Kelayakan kerja adalah Cukup Baik dengan Nilai akhir -1,2512711. Hasilnya berupa model aplikasi yang menjelaskan tentang hasil dari pengisian tiap kusioner oleh koresponden berupa puas atau tidak.
\end{abstract}

Keyword: Analisis, Kinerja Pegawai, Kualitas Kelayakan Kerja, Jaringan Syaraf Tiruan Propagasi Balik

\section{PENDAHULUAN}

Ketenagakerjaan merupakan aspek yang amat mendasar dalam kehidupan manusia karena mencakup dimensi sosial dan ekonomi. Salah satu tujuan penting dalam pembangunan ekonomi adalah menyediakan lapangan kerja yang cukup untuk mengejar pertumbuhan angkatan kerja, yang pertumbuhannya lebih cepat dari pertumbuhan kesempatan kerja.

Penilaian kinerja pegawai dalam organisasi merupakan hal yang sangat penting kerena akan bermanfaat untuk mengetahui efektifitas kerja organisasi sehingga tujuan organisasi tersebut akan dapat tercapai. Penilaian kinerja pegawai bagi organisasi swasta atau perusahaan belum memiliki ukuran yang baku, namun organisasi pemerintah atau instansi pemerintah sudah mempunyai aturan yang baku dalam penilaian kinerja pegawai dengan Daftar Penilaian Pelaksanaan Pekerjaan (DP3) yang dilakukan setiap akhir tahun. Berdasarkan Peraturan Pemerintah Nomor 10 Tahun 1979 tentang Penilaian Pelaksanaan Pekerja Pegawai Negeri Sipil, DP3 sebagai alat

(C) 2020 STIE TDN. All rights reserved 
penilaian kinerja pegawai di ukur dari segi kesetiaan, prestasi kerja, tanggung jawab, ketaatan, kejujuran, kerjasama, prakarsa dan kepemimpinan.

penilaian kinerja apabila kita tinjau lebih mendalam, penilaian kinerja pegawai akan dipengaruhi oleh beberapa hal antara lain motivasi, disiplin kerja, tingkat pendidikan, pengalaman kerja, pelatihan, komunikasi keterampilan dan sebagainya.

Perkembangan teknologi yang sangat pesat seiring dengan kebutuhan manusia yang semakin banyak dan kompleks memungkinkannya untuk digunakan secara luas di berbagai bidang seperti pada dunia bisnis, kesehatan, pendidikan, dan sebagainya.Peranan komputer sangat penting untuk membantu pekerjaan manusia sehari-hari dalam segala aspek bidang.Pemakai mulanya menggunakan komputer sebagai mesin ketik yang dapat bekerja lebih cepat, tepat maupun otomatis. Sejalan dengan perkembangan saat ini, para ahli mencoba menggantikan komputer menjadi suatu alat bantu yang dapat meniru cara kerja otak manusia, sehingga diharapkan suatu saat akan tercipta komputer yang dapat menimbang dan mengambil keputusan sendiri.

Hal inilah yang mendorong lahirnya teknologi AI (Artificial Intelligence).Salah satu teknik komputasi yang dikelompokkan dalam AI adalah Jaringan Syaraf Tiruan (Artificial Neural Network). Jaringan Syaraf Tiruan merupakan sistem pemrosesan informasi yang mempunyai penampilan karakteristik menyerupai jaringan syaraf biologi. Jaringan Syaraf Tiruan adalah salah satu alternatif pemecahan masalah dan banyak diminati oleh para peneliti pada saat ini. Hal ini karena keluwesan yang dimiliki oleh Jaringa Syaraf Tiruan, baik perancangan maupun dalam penggunaannya. Aplikasi Jaringan Syaraf Tiruan telah banyak dimanfaatkan dalam berbagai kepentingan, beberapa aplikasinya antara lain di dalam perbankan, telekomunikasi, dan kesehatan. Di bidang perbankan, Jaringan Syaraf Tiruan dapat digunakan memprediksi pemberian kredit, prediksi Kurs valuta asing, dan prediksi pasar saham.Di bidang kesehatan, Jaringan Syaraf Tiruan dalam mendiagnosa jenis penyakit menyimpan sejumlah data meliputi informasi pada gejala, deteksi, dan informasi lainnya.

Berdasarkan hal - hal tersebut diatas, maka perlu diketahui bagaimana memotivasi para pegawai meliputi keterampilan, pendidikan, pengalaman kerja, motivasi untuk mengetahui kualaitas kelayakan kerja pada kantor Dinas Kebersihan, Pertamanan dan Kebakaran Kab. Pinrang menggunakan jaringan syaraf tiruan backpropagation. Dengan demikian dapat diketahui instansi tersebut dapat lebih meningkatkan kinerja pegawainya dengan melakukan peningkatan atau perbaikan pada variabel yang ada, sehingga kinerja dari pegawai akan selalu mengalami peningkatan.

Dalam penelitian ini akan dilakukan rancangan sistem penilaian kerja pegawai dengan memperhitungkan faktor-faktor hasil pekerjaan dari pegawai dan hasil penilaian tersebut akan digunakan untuk menghitung kelayakan kualitas kerja pada Dinas Kependudukan dan Pencatatan Sipil Kab. Maros, yang dimaksudkan untuk pemberian insentif pegawai atau pun untuk mempertahankan pegawai tersebut. Diharapkan dengan sistem penilaian pekerjaan dapat menimbulkan rasa 
tanggung jawab terhadap pekerjaannya dan sekaligus memperbaiki kelemahan-kelemahan yang ada pada pegawai. Sedangkan bagi instans penilaian prestasi pegawai ini diharapkan dapat meningkatkan produktivitas dikarenakan kepuasan dan harmonisasi.

\section{TELAAH LITERATUR DAN PENGEMBANGAN HIPOTESIS}

\section{Jaringan Syaraf Tiruan (Backpropagation)}

Jaringan syaraf tiruan merupakan cabang dari Kecerdasan Buatan (Artificial Intelligence). JST adalah prosesor tersebar paralel (Paralel distributed procesor) yang sangat besar yang memiliki kecenderungan untuk menyimpan pengetahuan yang bersifat pengalaman dan membuatnya siap untuk digunaka. JST menyerupai otak manusia dalam 2 hal, yaitu : pengetahuan diperoleh jaringan melalui proses belajar, kekuatan hubungan antar sel syaraf (neuron) yang dikenal sebagai bobot-bobot sinaptik digunakan untuk menyimpan pengetahuaN.

Menurut Drs.Jong Jek Siang,M.Sc (2009, h.2) menyatakan bahwa jaringan syaraf tiruan adalah pemroses informasi yang memiliki karakteristik mirip dengan jaringan syaraf biologi. Pendapat yang sama juga diutarakan oleh Roza et.all \& Desiani dan Arhami (2006, h.160) yang menyatakan bahwa jaringan syaraf tiruan merupakan suatu sistem pemrosesan informasi yang memiliki karakteristik-karakteristik menyerupai jaringan syaraf biologi. Jaringan syaraf tiruan merupakan sebuah mesin yang dirancang untuk memodelkan cara otak manusia mengerjakan fungsi atau tugas-tugas tertentu
Secara umum, arsitektur jaringan syaraf tiruan terdiri atas beberapa lapisan, yaitu lapisan masukan (input layer), lapisan tersembunyi (hidden layer), dan lapisan keluaran (output layer). Masing-masing lapisan mempunyai node atau neuron yang berbeda-beda [6]. Arsitektur jaringan syaraf tiruan tersebut dapat diilustrasikan seperti gambar berikut ini :

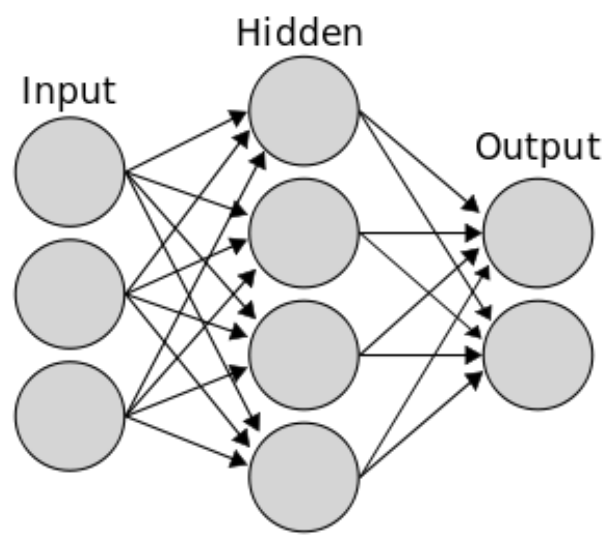

Gambar 1. Arsitektur Jaringan Syaraf Tiruan

1. Lapisan Masukan (Input Layer) Lapisan masukan merupakan lapisan yang terdiri dari beberapa neuron, yang akan menerima sinyal dari luar dan kemudian meneruskan ke neuron-neuron lain dalam jaringan. Lapisan ini diilhami berdasarkan cirri-ciri dan cara kerja sel-sel syaraf sensori pada syaraf biologi.

2. Lapisan Tersembunyi (Hidden Layer)

Lapisan tersembunyi merupakan tiruan dari sel-sel syaraf konektor pada jaringan syaraf biologis. Lapisan tersembunyi berfungsi meningkatkan kemampuan jaringan dalam memecahkan masalah. Konsekuensi dari adanya lapisan ini adalah pelatihan menjadi makin sulit atau lama.

3. Lapisan Keluaran (Output Layer) (C) 2020 STIE TDN. All rights reserved 
Lapisan keluaran berfungsi menyalurkan sinyal-sinyal keluaran hasil pemrosesan jaringan. Lapisan ini juga terdiri dari sejumlah neuron. Lapisan keluaran merupakan tiruan sel-sel saraf moto pada jaringan syaraf biologis.

Jaringan syaraf tiruan (JST) adalah model sistem komputasi yang bekerja seperti sistem syaraf biologis pada saat berhubungan dengan dunia luar, nama jaringan syaraf tiruan merupakan terjemahan dari "Artificial Neural Network".

Jaringan syaraf tiruan merupakan salah satu model untuk memperkirakan harga di masa datang memakai data deret waktu. Tiga hal yang sangat menentukan keandalan sebuah JST adalah pola rangkaian neuron-neuron dalam jaringan yang disebut dengan arsitektur jaringan algoritma untuk menentukan bobot penghubung yang disebut algoritma pelatihan, dan persamaan fungsi untuk mengolah masukan yang akan diterima oleh neuron yang disebut dengan fungsi aktivasi.

JST didefinisikan sebagai sistem komputasi yang didasarkan pada pemodelan saraf biologis (neuron) melalui pendekatan dari sifat-sifat komputasi biologis (biological computation). JST bisa dibayangkan berupa jaringan dengan elemen pemrosesan sederhana yang saling terhubung. Elemen pemrosesan berinteraksi melalui sambungan yang variabel, disebut bobot, dan bila diatur secara tepat dapat menghasilkan sifat yang diinginkan.

Untuk menyelesaikan permasalahan, JST memerlukan algoritma untuk belajar, yaitu bagaimana konfigurasi JST dapat dilatih untuk mempelajari data historis yang ada. Dengan pelatihan ini, pengetahuan yang terdapat pada data bisa diketahui dan direpresentasikan dalam bobot sambungannya.

Beberapa kegunaan jaringan syaraf tiruan dalam kehidupan nyata adalah sebagai berikut :

1. Pengenalan Pola

Jaringan syaraf tiruan dapat diapakai untuk mengenali pola (missal huruf, angka, suara, atau tanda tangan) yang sudah sedikit berubah. Hal ini mirip dengan otak manusia yang masih mampu mengenali orang yang sudah beberapa waktu tidak dijumpainya (mungkin wajah/bentuk tubuhnya sudah sedikit berubah).

2. Signal Processing

Jaringan syaraf tiruan dapat dipakai untuk menekan noise dalam sebuah telepon.

3. Peramalan

Jaringan syaraf tiruan juga dapat dipakai untuk meramalkan apa yang akan terjadi di masa yang akan datang berdasarkan pola kejadian yang ada di masa yang lampau. Ini dapat dilakukan mengingat kemampuan jaringan syaraf tiruan untuk mengingat dan mebuat generalisasi apa yang sudah ada sebelumnya.

\section{Pengambangan Hipotesis}

Penelitian terdahulu yang berkenaan dengan penelitian yang akan diangkat oleh penulis dapat dipaparkan di bawah ini :

Bagus (2014) melakukan penelitian tentang Analisis penilaian Kinerja Karyawan untuk mengetahui kualitas kelayakan kerja menggunakan jaringan syaraf tiruan backpropagation study kasus pada PG. Kebon Agung Malang. Penelitian ini menyimpulkan:

1. Jaringan Syaraf Tiruan (JST) Backpropagation yang telah dibuat dapat menentukan analisis (C) 2020 STIE TDN. All rights reserved 
kelayakan kualitas kerja seorang karyawan yang sesuai dengan karakteristik yang telah dimasukan kedalam pemrograman tersebut berdasarkan kreteria-kreteria yang telah ditentukan. Arsitektur JST yang digunakan adalah 23-1, yaitu 23 node pada lapisan input dan 1 node pada lapisan output.

2. Nilai Eps (error minimum yang diharapkan) Menggunakan; net.trainParam.epochs $=1000$, net.trainParam.goal $=1 \mathrm{e}-4$, dan feedforwardnet (hidden layer) $=5$. nilai tersebut merupakan nilai-nilai yang paling efektif dan efisien karena menggunakan nilai uji epoch sebanyak 1000x dan train goal yang memiliki tingkatan eror terkecil (0.00001) dalam melakukan analisis penilaian kualitas kinerja karyawan, sehingga diperoleh output dengan target yang paling baik, (sesuai dengan target yang telah diharapkan).

Willa (2016) melakukan penelitian tentang Pengaruh Pelayanan Laboratorium Klinik Cabang Makassar Terhadap Tingkat Kepuasan Konsumen Menggunakan Jaringan Saraf Tiruan Propagasi Balik. Hasil dari penelitian ini adalah : Menguraikan keterkaitan antara masing-masing variable bebas kualitas layanan yang terdiri atas Kehandalan, Daya Tanggap, Jaminan, Empati, dan Bukti Fisik yang berpengaruh terhadap kepuasan pelanggan yang berkaitan dengan jasa yang diberikan Laboratorium Klinik Prodia cabang Makassar.

$$
\text { Maria (2012) melakukan }
$$

penelitian tentang Penggunaan Jaringan Syaraf Tiruan Backpropagation untuk Seleksi Penerimaan Mahasiswa Baru Pada Jurusan Teknik Komputer di
Politeknik Negeri Sriwijaya. Hasil dari penelitian ini adalah hasil Analisa jaringan syaraf tiruan backpropagation dengan 1 hidden layer dengan jumlah neuron 50, iterasi 1000 dan fungsi aktivasi tansig menghasilkan regresi sebesar 0.4822 . Jaringan syaraf tiruan backpropagation dengan 2 hidden layer dengan jumlah neuron 50, iterasi 4000 dengan fungsi aktivasi tansig, menghasilkan regresi 0.7944. Jaringan syaraf tiruan backpropagation dengan 3 hidden layer dengan jumlah neuron 35 , iterasi 5000, menghasilkan regresi sebesar 0.8563 .

\section{METODE PENELITIAN}

\section{Kerangka Konseptual}

Sumber daya manusia merupakan satu-satunya sumber daya yang paling potensial dan strategis dalam setiap organiasi sehingga sangat penting untuk mengetahui potensi yang dimiliki tenaga kerja, yang kemudian di kembangkan sebagaimana mestinya agar dapat memberikan nilai tambah atas imbalan bagi organisasi dalam bentuk peningkatan kinerja pegawai yang berkualitas.

Kualifikasi pengetahuan dan potensi yang dimiliki oleh pegawai adalah Pendidikan, Keterampilan, yang di peroleh melalui pelatihan tekhnis dan pelatihan struktural, pengalaman dan motivasi kerja merupakan satu hal yang dibutuhkan untuk memastikan bahwa pegawai mempunyai kontribusi terhadap peningkatan kinerja pegawai dalam organisasi. Ini merupakan penjabaran dari tugas pokok dan fungsi untuk merencanakaN.

Dalam suatu organisasi dimana saat sekarang ini kemampuan intelektual atau ilmu pengetahuan dan ketarampilan dari sumber daya manusia sangat dibutuhkan organisasi untuk dapat mengembangkan

(C) 2020 STIE TDN. All rights reserved 
kemampuan kearah visi dan misi organisasi.

Untuk mengatahui kualitas kelayakan kerja pada pegawai Dinas kebersihan, pertamanan dan kebakaran Kab. Pinrang maka di perlukan setidaknya empat variabel yang dapat digunakan untuk melakukan penilaian kinerja diantaranya keterampilan, pendidikan, pengalaman kerja dan motivasi. Keempat variabel tersebut memiliki 21 indikator dimana pada satiap indikator di beri nilai bobot untuk kemudian di proses menggunakan jaringan syaraf tiruan backpropagation. Indikator tersebut akan diberikan kode khusus yang mengidentifikasikan indikator pada saat akan di berikan bobot. dapat dilihat pada Tabel 1.

Tabel 1. Pengkodean Indikator

\begin{tabular}{|c|c|c|}
\hline Variabel & Indikator & Kode \\
\hline \multirow{4}{*}{$\begin{array}{l}\text { Keterampilan } \\
\text { (X1) }\end{array}$} & $\begin{array}{l}\text { Mampu menguasai alat dan fasilitas } \\
\text { kantor }\end{array}$ & $\left(\mathrm{X} 1_{1}\right)$ \\
\hline & $\begin{array}{l}\text { Mengerjakan tugas dan tanggung jawab } \\
\text { yang di amanahkan }\end{array}$ & $\left(\mathrm{X} 1_{2}\right)$ \\
\hline & $\begin{array}{l}\text { Mampu membantu pegawai lain yang } \\
\text { kesulitan }\end{array}$ & $\left(\mathrm{X} 1_{3}\right)$ \\
\hline & $\begin{array}{l}\text { Siap dibantu oleh pegawai lain yang lebih } \\
\text { kompeten }\end{array}$ & $\left(\mathrm{X} 1_{4}\right)$ \\
\hline \multirow{4}{*}{ Wahyudi (2002) } & $\begin{array}{l}\text { Kemampuan melakukan kerja sama } \\
\text { dengan rekan kerja }\end{array}$ & $\left(\mathrm{X} 1_{5}\right)$ \\
\hline & $\begin{array}{l}\text { Usaha untuk meminimalkan kesalahan } \\
\text { dalam melakukan pekerjaan }\end{array}$ & $\left(\mathrm{X} 1_{6}\right)$ \\
\hline & $\begin{array}{llr}\text { Kemampuan memahami setiap } \\
\text { perkembangan linformasi baru } & \text { yang } \\
\text { berhubungan dengan pekerjaan } & \end{array}$ & $\left(\mathrm{X} 1_{7}\right)$ \\
\hline & $\begin{array}{l}\text { Hasil kerja setiap mendapatkan tugas } \\
\text { dari atasan }\end{array}$ & $\left(\mathrm{X} 1_{8}\right)$ \\
\hline \multirow[t]{2}{*}{$\begin{array}{l}\text { Pendidikan } \\
\text { (X2) }\end{array}$} & $\begin{array}{l}\text { Latar belakang } \text { Pendidikan sesuai } \\
\text { dengan pekerjaan }\end{array}$ & $\left(\mathrm{X} 2_{1}\right)$ \\
\hline & Pendidikan akan membentuk kepribadian & $\left(\mathrm{X} 2_{2}\right)$ \\
\hline
\end{tabular}

\begin{tabular}{|c|c|c|}
\hline \multirow{3}{*}{$\begin{array}{c}\text { Dhina Sari } \\
\text { (2010) }\end{array}$} & pegawai & \multirow[b]{2}{*}{$\left(\mathrm{X} 2_{3}\right)$} \\
\hline & $\begin{array}{l}\text { Pengetahuan yang memadai untuk } \\
\text { menyelesaikan pekerjaan }\end{array}$ & \\
\hline & $\begin{array}{l}\text { Tanggapan rekan kerja atau atasan } \\
\text { terkait ide-ide dalam menyelesaikan } \\
\text { pekerjaan }\end{array}$ & $\left(X 2_{4}\right)$ \\
\hline \multirow{2}{*}{$\begin{array}{l}\text { Pengalaman } \\
\text { Kerja } \\
\text { (X3) }\end{array}$} & $\begin{array}{l}\text { Pengalaman kerja yang membantu } \\
\text { menyelesaikan tugas dengan baik }\end{array}$ & $\left(X_{1}\right)$ \\
\hline & $\begin{array}{l}\text { Pemanfaatan waktu kerja dan tidak } \\
\text { membuang-buang waktu dengan } \\
\text { kegiatan lain yang tidak berkaitan dengan } \\
\text { pekerjaan }\end{array}$ & $\left(\mathrm{X}_{2}\right)$ \\
\hline \multirow{2}{*}{$\begin{array}{l}\text { Isti yulyaeni } \\
\qquad(2014)\end{array}$} & $\begin{array}{l}\text { Penyelesaian pekerjaan sesuai dengan } \\
\text { prosedur yang benar }\end{array}$ & $\left(\mathrm{X}_{3}\right)$ \\
\hline & $\begin{array}{l}\text { Membantu mengurangi kesalahan pada } \\
\text { saat pengerjaan tugas }\end{array}$ & $\left(X_{4}\right)$ \\
\hline \multirow{3}{*}{$\begin{array}{l}\text { Motivasi } \\
\text { (X4) }\end{array}$} & Upah yang sesuai dengan pekerjaan & $\left(\mathrm{X} 4_{1}\right)$ \\
\hline & $\begin{array}{lll}\begin{array}{l}\text { Pekerjaan ini mendorong untuk } \\
\text { berprestasi }\end{array} & & \\
\end{array}$ & $\left(\mathrm{X} 4_{2}\right)$ \\
\hline & $\begin{array}{l}\text { Bekerja secara maksimal untuk mencapai } \\
\text { prestasi kerja yang tinggi }\end{array}$ & $\left(\mathrm{X} 4_{3}\right)$ \\
\hline \multirow{2}{*}{$\begin{array}{l}\text { Stefiany } \\
(2015)\end{array}$} & $\begin{array}{l}\text { Mendapat pengakuan dari rekan kerja } \\
\text { atas prestasi kerja yang dicapai }\end{array}$ & $\left(\mathrm{X} 4_{4}\right)$ \\
\hline & $\begin{array}{l}\text { Usaha untuk melalakukan pekerjaan } \\
\text { yang baik untuk mendapatkan pengakuan } \\
\text { dari pimpinan }\end{array}$ & $\left(\mathrm{X} 4_{5}\right)$ \\
\hline
\end{tabular}

Dari Tabel 1 ini, peneliti dapat menggambarkan kerangka konseptual dan hipotesis yang akan di pakai saat penelitian sebagai pola atau gambaran yang akan dilakukan.

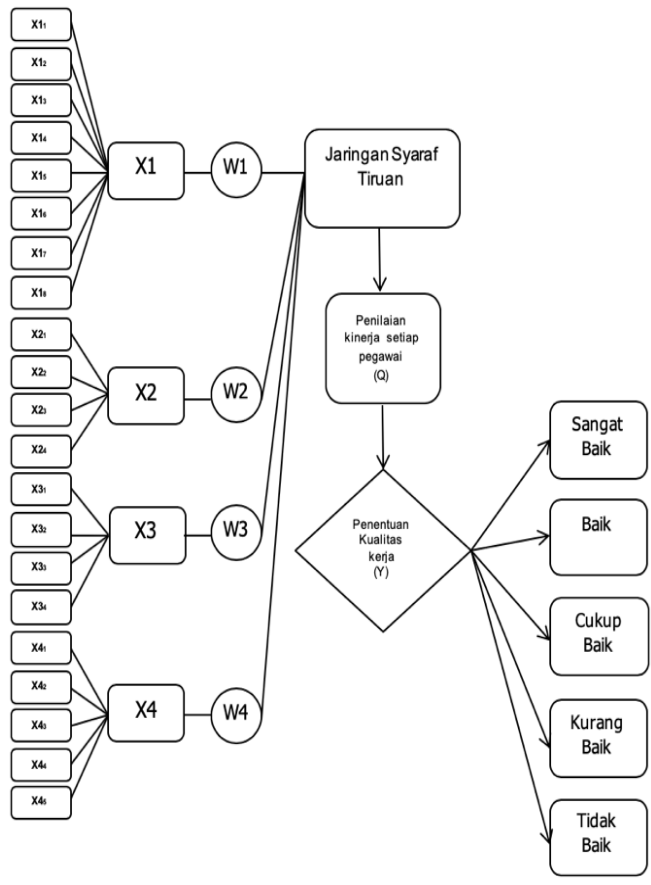

Gambar 3. Kerangka Konseptual Keterangan

- $\mathrm{X} 1_{1}-\mathrm{X} 4_{5}$

(C) 2020 STIE TDN. All rights reserved 
Adalah 21 indikator yang dihasilkan dari 4 variabel yang merupakan unit inputan.

- X1-X4

Adalah variabel yang meliputi keterampilan, pendidikan, pengalaman kerja dan motivasi

- W1 - W4

Adalah nilai bobot Akhir yang di proses pada hidden layer

- Jaringan Syaraf Tiruan

Adalah tahap analisa perhitungan dengan menggunakan jaringan syaraf tiruan propagasi balik.

- Penilaian Kinerja

Adalah hasil penilaian pada setiap pegawai dari proses perhitungan pembobotan X11 - X45 menggunakan JST.

- Penentuan Kualitas Kerja

Adalah tahap bagian penentuan hasil akhir dari penilaian kinerja setiap pegawai menggunakan JST yang memberikan hasil output pada instansi apakah termasuk dalam kategori sangat baik, baik, cukup baik, kurang baik, dan tidak baik.

\section{HASIL PENELITIAN DAN PEMBAHASAN}

\section{Hasil Analisis}

\section{Analisis proses jaringan syaraf tiruan Bacppropagation}

Maka dapat digambarkan dalam struktur algoritma sebagai dasar dari pemodelan struktur atau cara kerja JST (backpropagation), dengan memiliki tiga tahap untuk menghasilkan output adalah Input -> Hidden Layer (Proses) -> Output. Seperti gambar berikut ini:

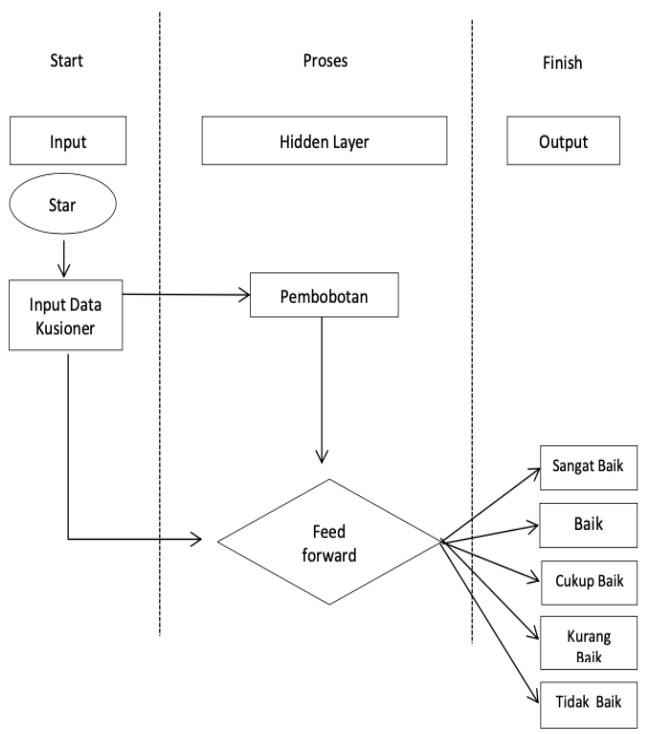

Gambar 4. Stuktur Algoritma

Dari gambar flowchat algoritma di atas maka dapat dilakukan simulasi dengan menggunakan kode masingmasing unsur dalam 4 bagian dengan menggunakan metode Algoritma Jaringan Syaraf Tiruan Backpropagation. Sebagai berikut :

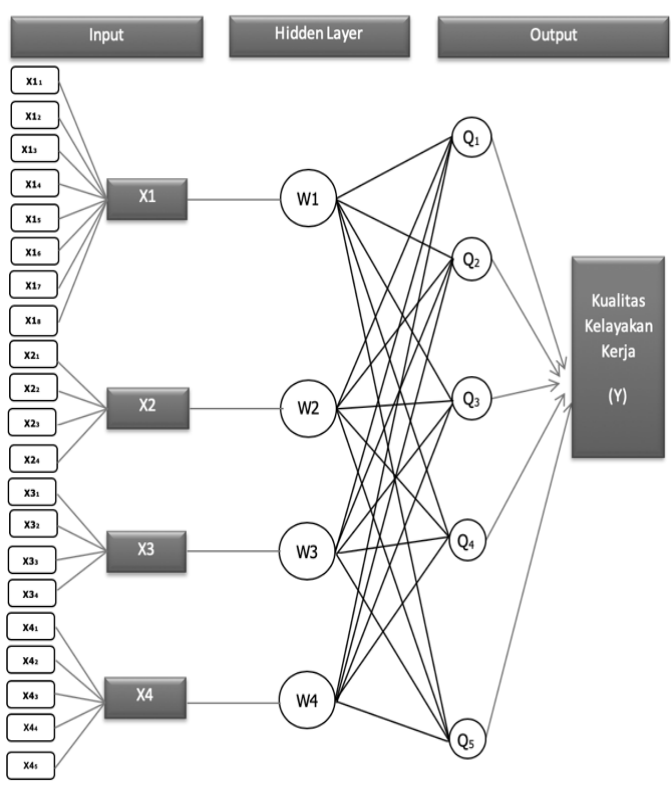

Gambar 5. Cara Kerja Jaringan Syaraf Tiruan Propagasi-balik 
Keterangan Gambar:

- Input:

Pada tahap ini 21 indikator merupakan inputan yang mendefinisikan 4 Variabel. Inputan di peroleh dari data kuesioner dari masing-masing pegawai.

- Hidden Layer:

Pada tahap ini merupakan lapisan tersembunyi (hidden layer) dimana terdapat 4 Variabel yang dibentuk dari 21 indikator. 4 Variabel tersebut diberi nilai bobot awal dan akan diproses menggunkan jaringan syaraf tiruan propagasi balik sehingga menghasilkan nilai bobot akhir.

- Output:

Pada tahap ini terdapar dua output, output pertama yaitu penilaian kinerja apakah pegawai tersebut termasuk dalam kategori Sangat Baik, Baik, Cukup Baik, Kurang Baik dan Tidak Baik yang kemudian di simbolkan dalam Q1 - Q5. Output kedua yaitu kualitas kelayakan kerja pada Dinas Kependudukan dan Pencatatan Sipil Kab. Maros.

\section{Pembahasan}

\section{Gambaran Umum Aplikasi}

Dari data yang telah terkumpul melalui responden kemudian mendapatkan skor dari kuesioner yang telah dibagikan kepada responden, langkah berikutnya adalah pengolahan data dengan menggunakan Aplikasi berbasis Java NetBeans IDE 8.2 yang telah dibuat. Pada penelitian ini menghasilkan sebuah Aplikasi untuk menganalisis penilaian kinerja pegawai untuk mengetahui kualitas kelayakan kerja.
Dalam Aplikasi tersebut proses pengukuran dilakukan dengan menggunakan metode Jaringan Syaraf Tiruan atau Artificial Neural Network (ANN) dengan model proses Backpropagation. Model Backpropagatian menjadi salah satu teknik yang paling sering digunakan dalam menyelesaikan masalah dibidang pengukuran. Adapun Arsitektur yang di hasilkan dapat di lihat pada gambar di bawah ini :

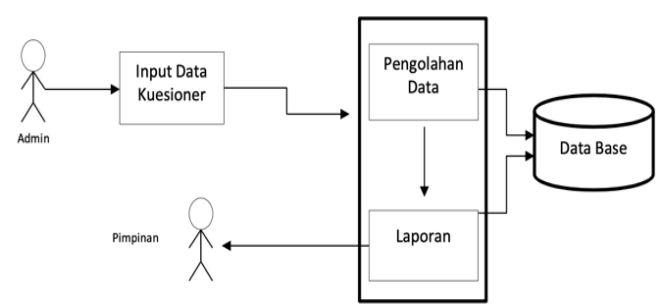

Gambar 6. Arsitektur Aplikasi menganalisis penilaian kinerja pegawai untuk mengetahui kualitas kelayakan kerja

Articial Neural Network adalah suatu model yang merupakan analogi dari jaringan syaraf biologis untuk dapat diterapkan ke dalam sistem komputasi sehingga sistem diharapkan dapat belajar untuk mengenali polapola dari data yang dilatihkan kepadanya. Oleh sebab itu Jaringan Syarat Tiruan atau Artificial Neural Network telah banyak digunakan untuk prediksi, pengenalan pola, klasifikasis dan sebagai alat bantu pengukuran[19], [20].

Neoron pada desain konsep Artificial Neural Network pada analisis penilaian kinerja pegawai untuk mengetahui kualitas kelayakan kerja sebagai berikut :

a. Input. Bagian sistem yang digunakan untuk menerima masukan, dalam Aplikasi penilaian kinerja pegawai untuk mengetahui kualitas kelayakan 
kerja dan yang menjadi input adalah:

$\checkmark$ Mampu menguasai alat dan fasilitas kantor $\left(\mathrm{X} 1_{1}\right)$

$\checkmark$ Mengerjakan tugas dan tanggung jawab yang di amanahkan $\left(\mathrm{X}_{2}\right)$

$\checkmark$ Mampu membantu pegawai lain yang kesulitan $\left(\mathrm{X}_{3}\right)$

$\checkmark$ Siap dibantu oleh pegawai lain yang lebih kompeten $\left(\mathrm{X}_{4}\right)$

$\checkmark$ Kemampuan melakukan kerja sama dengan rekan kerja $\left(\mathrm{X}_{5}\right)$

$\checkmark$ Usaha untuk meminimalkan kesalahan dalam melakukan pekerjaan $\left(\mathrm{X}_{6}\right)$

$\checkmark$ Kemampuan memahami setiap perkembangan /informasi baru yang berhubungan dengan pekerjaan $\left(\mathrm{X}_{7}\right)$

$\checkmark$ Hasil kerja setiap mendapatkan tugas dari atasan $\left(\mathrm{X}_{8}\right)$

$\checkmark$ Latar belakang Pendidikan sesuai dengan pekerjaan $\left(\mathrm{X} 2{ }_{1}\right)$

$\checkmark$ Pendidikan akan membentuk kepribadian pegawai $\left(\mathrm{X}_{2}\right)$

$\checkmark$ Pengetahuan yang memadai untuk menyelesaikan pekerjaan $\left(\mathrm{X} 2{ }_{3}\right)$

$\checkmark$ Tanggapan rekan kerja atau atasan terkait ide-ide dalam menyelesaikan pekerjaan $\left(\mathrm{X} 2{ }_{4}\right)$

$\checkmark$ Pengalaman kerja yang membantu menyelesaikan tugas dengan baik (X3 $\left.3_{1}\right)$

$\checkmark$ Pemanfaatan waktu kerja dan tidak membuang-buang waktu dengan kegiatan lain yang tidak berkaitan dengan pekerjaan $\left(\mathrm{X} 3_{2}\right)$

$\checkmark$ Penyelesaian pekerjaan sesuai dengan prosedur yang benar $\left(\mathrm{X} 3_{3}\right)$

$\checkmark$ Membantu mengurangi kesalahan pada saat pengerjaan tugas $\left(\mathrm{X}_{4}\right)$

$\checkmark$ Upah yang sesuai dengan pekerjaan $\left(\mathrm{X} 4{ }_{1}\right)$
Pekerjaan ini mendorong untuk berprestasi $\left(\mathrm{X} 4_{2}\right)$

$\checkmark$ Bekerja secara maksimal untuk mencapai prestasi kerja yang tinggi $\left(\mathrm{X}_{3}\right)$

$\checkmark$ Mendapat pengakuan dari rekan kerja atas prestasi kerja yang dicapai $\left(\mathrm{X}_{4}\right)$

$\checkmark$ Usaha untuk melalakukan pekerjaan yang baik untuk mendapatkan pengakuan dari pimpinan $(\mathrm{X} 45)$

b. Weight (Bobot). Merupakan bobot penilaian yang diberikan pada setiap inputan, merupakan penghububung yang berfungsi untuk meningkatkan dan menurunkan nilai dari informasi agar sesuai dengan target. Nilai dari bobot akan berubah setiap kali diberikan input untuk pembelajaran dan akan tetap ketika output pembelajaran telah sesuai objek yang diinginkan.

c. Processing Unit. Bagian terjadinya proses komputasi yang pada sistem analisis penilaian kinerja pegawai untuk mengetahui kualitas kelayakan kerja ini akan melakukan proses penilaian kinerja pada masin-masing pegawai dan proses mengetahui kualitas kelayakan kerja berdasarkan nilai yang diperolah dari pengimputan disertakan bobot yang telah di tentukan sebelumnya.

\section{Perancangan Aplikasi}

Perancangan sistem diawali dengan identifikasi permasalahan, analisis masalah, menggunakan metode yang telah ditentukan untuk menyelesaikan masalah, pembuatan Aplikasi, pengolahan data di mulai dari Input data, proses data, hingga menghasilkan output yang menjadi tujuan utama dari penelitian ini. 


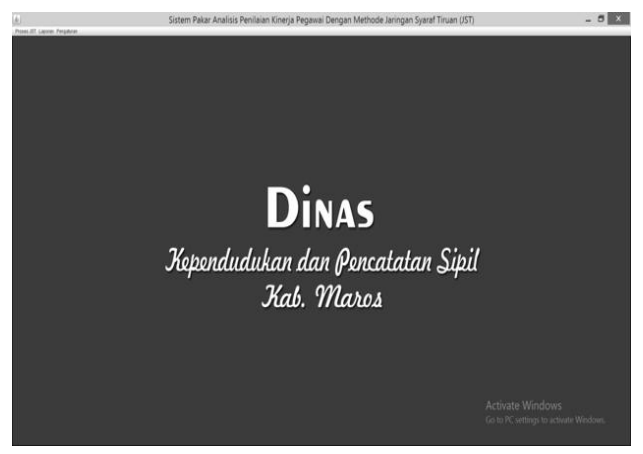

Gambar 7. Tampilan Menu Utama

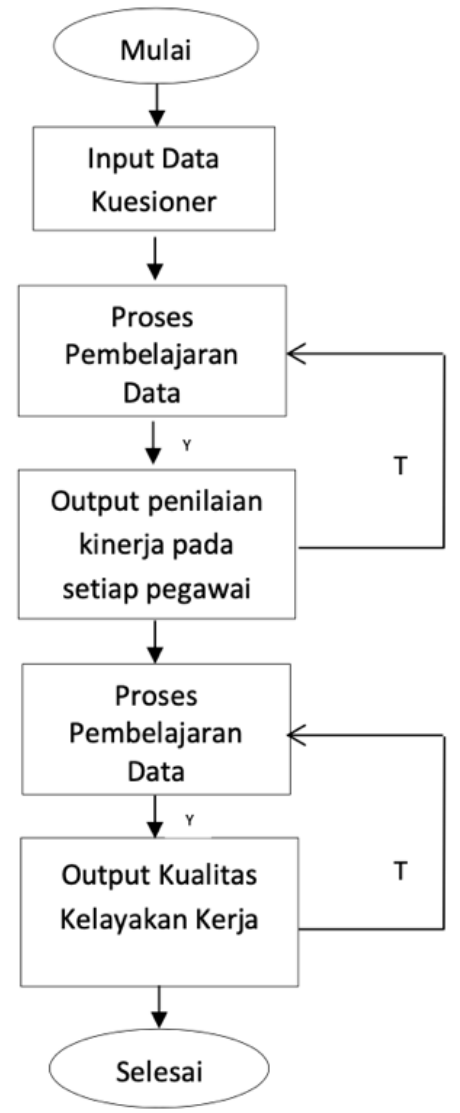

Gambar 8. Gambaran Umum Aplikasi

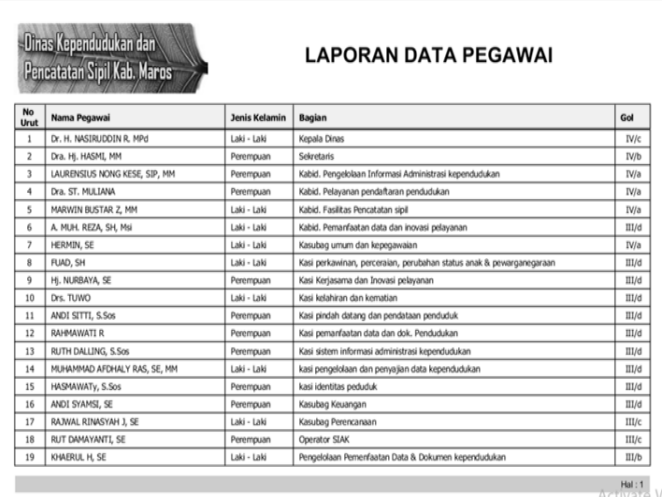

Gambar 9. Laporan Data Pegawai
Pada Gambar 9 merupakan laporan keselurahan data pegawai yang telah mengisi kusioner kemudian telah tersimpan di dalam database.

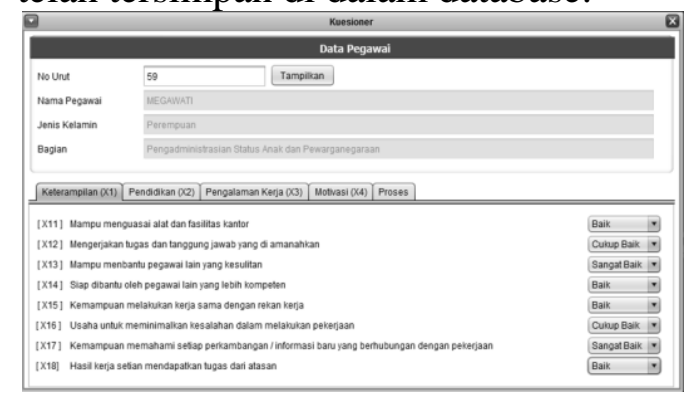

Gambar 10. Input Data Kuesioner

Untuk output seluruh hasil penilaian kinerja pegawai yang sebelumnya telah diisi disimpan dalam laporan yang berbentuk seperti form berikut:

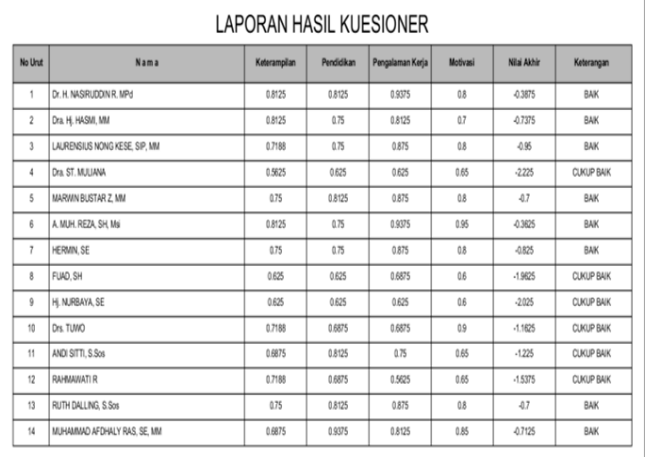

Gambar 11. Laporan penilaian kinerja pegawai

Pada Gambar 11. menunjukkan tampilan laporan hasil penyimpanan dari database berupa seluruh hasil penilaian dari setiap pegawai yang telah mengisi kusioner.

\section{KESIMPULAN DAN SARAN Kesimpulan}

Berdasarkan uraian dan hasil analisis yang ditunjukkan pada bab sebelumnya, dapat disimpulkan hal-hal sebagai berikut : 
1. Jaringan Syaraf Tiruan (JST) Backpropagation yang telah dibuat dapat menentukan analisis kelayakan kualitas kerja yang sesuai dengan indikator yang telah dimasukan kedalam pemrograman tersebut dan memberikan teknik pengelolaan data yang akurat.

2. Penilaian Kinerja Pegawai pada Kantor Dinas Kependudukan dan Pencatatan Sipil kabupaten Maros dengan jumlah pegawai 59 orang adalah sebanyak 21 orang pegawai nilai kinerjanya Baik dan 38 orang pegawai nilai kinerjanya Cukup Baik.

3. Kualitas Kelayakan kerja pada Kantor Dinas Kependudukan dan Pencatatan Sipil kabupaten Maros dengan jumlah pegawai 59 orang adalah Cukup Baik dengan Nilai akhir -1,2512711.

\section{Saran}

Berdasarkan kesimpulan diatas, maka diajukan beberapa saran sebagai berikut:

1. Kiranya pengembangan portal informasi yang diperlukan untuk membantu dalam melakukan Penilaian Kinerja Pegawai untuk mengetahui kuaitas kelayakan kerja dapat dijadikan media yang tepat bagi penggunanya, dalam menerima informasi yang akurat, terpercaya, dan memiliki nilai yang efektif serta efisien bagi pengguna

2. Dilakukan pengembangan program sejenis dengan permasalahan domain yang lebih luas.

3. Data mengenai Indikator dan semua mengenai penilaian kinerja dan kualitas kelayakan kerja kiranya dapat lebih dimaksimalkan, sampai mendapatkan perhitungan probabilitas yang lebih akurat serta dicari alternative lain yang memungkinkan penyelesaian yang jauh lebih baik.

\section{DAFTAR PUSTAKA}

Ginting and S. Sasmita, "Pengaruh Tingkat Pendidikan Dan Motivasi Terhadap Kinerja Pegawai Pada Pdam Tirtanadi Cabang Sei Agul Medan," Repos. Univ. Sumatera Utara, 2015.

Suyanto, Artificial Intelligence. Informatika Bandung, 2011.

G. Hermawan, "Jurnal Ilmiah Komputer dan Informatika ( KOMPUTA ) GAME SHOPPING TIME," vol. 2, no. April, 2016.

P. Roza and M. Junjung, "Implementation of Artificial Neural Network (ANN) for Prediction of Students High School Graduations," J. Sains dan Inform., vol. 4, no. 1, pp. 11-22, 2018.

Bernardin and Russel, Manajemen Sumber Daya Manusia. Bandung, 2006.

Dessler and Gary, Human Resource Management. New Jersey, 2003.

S. Wahyuddin, F. I. Estiko, and E. Rijanto, "Analysis of Factors Affecting Tuition Fee in a Private University: A Data Mining Using VAR Model," IOP Conf. Ser. Mater. Sci. Eng., vol. 662, p. 022050, 2019.

T. Sylvia, A. Hidayat, and S. A. Putri, "Berdasarkan Kompetensi Dengan Menggunakan Metode Analytic Network Process ( Anp ) Dan Rating Scale ( Studi Kasus Di Pg. Pesantren Baru, Kediri ) Competency- Based Performance Appraisal for (C) 2020 STIE TDN. All rights reserved 
Human Resouces Departement, S Staffs With Analytic Network Proc," vol. 2, no. 2, pp. 131142, 2013.

M. Pradana, "Pengaruh Gaya Kepemimpinan Terhadap Motivasi Karyawan di Ganesha Operation , Bandung," J. Stud. Manaj. Dan Bisnis, vol. 2, no. 1, pp. 24-39, 2015.

Yuwalliatin and Siity, "Pengaruh Budaya Organisasi, Motivasi Dan Komitmen Terhadap Kinerja Serta Pengaruhnya Terhadap Keunggulan Kompetitif Dosen UNISULA Semarang.," vol. 7, pp. 241256, 2006.

Suharto and Cahyo, "Pengaruh Budaya

Organisasi, Kepemimpinan Dan

Motivasi Terhadap Kinerja

Sumber Daya Manusia Di

Sekretariat DPRD Propinsi Jawa

Tengah.," J. Ris. Bisnis Indones., vol. 1, pp. 13-30, 2005.

Yulyaeni and Isti, "Pengaruh Kepemimpinan, Pengalaman Kerja, dan Motivasi Kerja Terhadap Kinerja Karyawan Pada RSUD Kayen Kabupaten Pati," 2014.

H. Hapid and A. R. Sunarwan, "Pengaruh Gaya

Kepemimpinan, Motivasi Dan Disiplin Kerja Terhadap Kinerja Karyawan Pt. Financia Multi Finance Palopo," J. Ekon. Pembang. STIE

Muhammadiyah Palopo, vol. 1, no. 2, pp. 7-16, 2016.

S. Muchtar and Zul Rachmat,
"Pengaruh Lelang Jabatan, Kepemimpinan dan Kompetensi Terhadap Kinerja Kepala Sekolah di Kota Makassar," MOVERE J., vol. 1, no. 1, pp. 93-101, 2019.

Zul Fadli, “Analisis Motivasi Pegawai Kantor Kecamatan Lalabata Kabupaten Soppeng," Ibnu Khaldum, vol. 13, no. 3, pp. 626-639, 2018.

Pabundu and Tika, Budaya Organisasi dan Peningkatan Kinerja Perusahaan. Jakarta: PT. Bumi Aksara, 1996.

Zul Rachmat, "Penggaruh Gaya Kepemimpinan, Motovasi, dan Lingkungan Kerja Terhadap Kinerja Pegawai Pada Dinas Pendapatan Pengelolaan Keungan dan Aset Daerah Kabupaten Soppeng," Universitas Muslim Indonesia, 2015.

W. S. Fauzi Insan Estiko, "Economics Development Analysis Journal Analysis of Indonesia's Inflation Using ARIMA and Artificial Neural Network Article Information," Econ. Dev. Anal. J., vol. 8, no. 2, pp. 151-162, 2019.

Zulrachmat, Zulfadli, and S. Wahyuddin, "The Effect of Inflation to the Rise of Tuition Fee in University," SENSITIF, pp. 1055-1061, 2019.

C. Burton and F. R, "Planning and Management for a canging environment," 1997. 
ISSN 2656-2790 (online) 